\title{
KETERLIBATAN MASYARAKAT DALAM PENGEMBANGAN OBJEK WISATA DI KECAMATAN LUBUK ALUNG DAN BATANG ANAI KABUPATEN PADANG PARIAMAN (Studi Kasus: Air Terjun Nyarai, Tapian Puti dan Rumah Pohon Manang)
}

\author{
MelyaFebriani ${ }^{1}$, Ahyuni $^{2}$ \\ Program Studi Pendidikan Geografi, \\ Fakultas Ilmu Sosial, Universitas Negeri Padang
}

\begin{abstract}
Abstrak
Penelitian ini bertujuan mendapatkan informasi mengenai keterlibatan masyarakat dalam pengembangan objek wisata. Penelitian ini mengunakan pendekatan deskriptif kualitatif, untuk mendeskripsikan pencetus, bentuk penjalaran keterlibatan masyarakat, aturan, persamaan dan perbedaan keterlibatan masyarakat. Temuan hasil penelitian yaitu pencetus objek wisata Air Terjun Nyarai adalah Ritno Kurniawan, objek wisataTapian Puti adalah Pemuda Sikabu Bukik, sedangkan Rumah Pohon Manang dicetus oleh masyarakat dan LSM (Lembaga Swadaya Masyarakat). Penjalaran Keterlibatan masyarakat Air Terjun Nyarai mulai dari individu, Pokdarwis (Kelompok Sadar Wisata) dan LPHN (Lembaga Pengelolaan Hutan Nagari). Keterlibatan masyarakat Tapian Puti dimulai dari niniak mamak kemudian pemuda-pemudi Sikabu Bukik, sedangkan objek wisata Rumah Pohon Manang di mulai dari LPHN kemudian membentuk Pokdarwis. Ketiga objek wisata ini terikat oleh aturan adat, tapi objek wisata Air Terjun Nyarai \& Rumah Pohon Manang memiliki aturan tertulis yang mengikat. Persamaan ketiga objek wisata ini merupakan objek wisata minat khusus, dan berada pada hutan lindung blok bukit barisan 1 (satu). Sedangkan perbedaannya dapat terlihat dari cara terbentuk dan pengelolaannya oleh masyarakat di sekitar objek wisata tersebut.
\end{abstract}

\section{Kata Kunci : Keterlibatan Masyarakat, Objek Wisata}

\begin{abstract}
The purpose of research is to describe the community involvement in three of tourism objects in Padang Pariaman Regency. This research uses qualitative method to describe the initiator, community involvement, rule of conduct, and also similarities and differences pattern of community involvement in the three cases. Initiator of Nyarai Waterfall is Ritno Kurniawan, and at Tapian Puti is the youth of Sikabu Bukik, while at Manang Tree House initiate by the community and NGO (Non-Governmental Organization). Community involvement of Nyarai Water fall started by personal initiative, then followed by Pokdarwis (Tourism Awareness Group) and LPHN (Village Forest Management Institution) while at Tapian Puti niniak mamak taken initiative together with youth group of Sikabu Bukik, while at the Manang Tree House, LPHN initiated and followed by formed new Pokdarwis. These three tourism objects already had traditional rule that could be used for tourist activity, but only Nyarai Water fall and Manang Tree House had own legal written rule. These three tourism objects are a kind of special interest tourism as their similarity, and the differences can be found in type of actor as initiator and management pattern of community invovement.
\end{abstract}

Keywords: Community Involvement, Tourism Object.

\footnotetext{
${ }^{1}$ Alumni Program Studi Pendidikan Geografi Universitas Negeri Padang. Email: melya.febriani@gmail.com

${ }^{2}$ Dosen Jurusan Geografi Fakultas Ilmu Sosial Universitas Negeri Padang Email: ahyuniaziz@ fis.unp.ac.id
} 


\section{PENDAHULUAN}

Memasuki abad ke-21 pariwisata diramalkan menjadi kegiatan industri terbesar di dunia, dibandingkan dengan sektor-sektor ekonomi lainnya. Fenomena ini menyebabkan banyak negara, wilayah, masyarakat maupun investor di dunia mulai melirik, terjun dan melibatkan diri dalam dunia kepariwisataan.

Pariwisata yang memanfaatkan keindahan alam dalam pengelolaannya harus memperhatikan pemanfaatan lingkungan sehingga tidak merusak, apalagi menyebabkan kerusakan ekosistem. Pengembangan pariwisata baik itu wisata alam, sosial, maupun budaya diharapkan memberikan manfaat lansung kepada masyarakat setempat, baik itu secara ekonomi, sosial, budaya, dan lingkungan.

Wacana pembangunan sebuah objek wisata tentunya memerlukan rencana yang matang, apabila tidak ada rencana pengelolaan dan promosi pariwisata yang matang, maka maka objek wisata tersebut tidak akan bertahan lama. Wacana pembangunan pariwisata yang melibatkan masyarakat lokal sebagai pengelolanya memerlukan rencana yang matang, karena masyarakat lokal memiliki peran penting dalam pengembangan pariwisata terlebih lagi mereka lebih tahu mengenai kondisi lingkungan objek wisata dengan baik. Masyarakat setempat merupakan elemen penting dalam pengembangan pariwisata berbasis lokal, karena mereka adalah elemen dasar dari pengembangan pariwisata modern.
Pariwisata merupakan bagian yang tak terpisahkan dari pembanguan suatu daerah, seperti dalam Undangundang Nomor 10 tahun 2009 pasal $3 \& 4$ tentang kepariwisataan yang berbunyi :

"Kepariwisataan berfungsi memenuhi kebutuhan jasmani, rohani, dan intelektual setiap wisatawan dengan rekreasi dan perjalanan, serta meningkatkan pendapatan negara untuk mewujudkan kesejahteraan rakyat. Kepariwisataan bertujuan untuk (1) meningkatkan pertumbuhan ekonomi, (2) meningkatkan kesejahteraan rakyat (Undang-undang Republik Indonesia Nomor 10 tahun 2009 tentang Kepariwisataan)

Keterlibatan masyarakat setempat dalam pengembangan objek wisata dapat megoptimalkan potensi yang dimilikiolehsebuah objek wisata, karena masyarakat setempat dapat mengelola dan memelihara objek wisata itu dengan sebaik-baiknya. Menjaga kelestarian alam merupakan salah satu unsur pokok agar wisata alam ini dapat dinikmati oleh generasi sekarang dan generasi mendatang.

Secara etimologis pariwisata terdiri dari dua suku kata yaitu "Pari" dan "Wisata". Pari berarti banyak, berkali kali atau keliling dan wisata berarti perjalanan, berpergian. Karena itu "Pariwisata" diartikan sebagai perjalanan yang dilakukan berkali-kali, atau berputar-putar dari satu tempat ketempat yang lain. Menurut Bahasa Inggris pariwisata disebut dengan "tour" sedangkan untuk pengertian jamak kata "kepariwisataan" dapat digunakan kata 
"tourisme" atau "tourism". (Bakarudin, 2008:12).

Menurut Yoeti dalam Utama (2012:107) syarat suatu perjalanan disebut sebagai pariwisata apabila:

a. Perjalanan dilakukan dari suatu tempat ke tempat yang lain, di luar tempat kediaman orang tersebut biasa tinggal

b. Tujuan perjalanan semata-mata untuk bersenang-senang, dan tidak mencari nafkah di tempat atau negara yang dikunjunginya

c. Semata-mata sebagai konsumen di tempat yang dikunjungi

Objek wisata atau tourism attractions adalah segala sesuatu yang menjadi daya Tarik bagi orang untuk mengunjungi suatu daerah tertentu (Yoeti, 1996:172). Sedangkan menurut Suwanto (2004:19) dalam bukunya "Dasar-dasar pariwisata" mengatakan bahwa daya Tarik wisata/objek wisata merupakan potensi yang menjadi pendorong kehadiran wisatawan kesuatu daerah tujuan wisata.

\section{Community}

(masyarakat setempat) merupakan salah satu komponen untuk memahami masyarakat dalam pengembangan pariwisata, tetapi juga penting untuk mengetahui bagaimana masyarakat mempengaruhi pengembangan pariwisata daerah (Aref, 2010).

Kelompok Sadar Wisata (Pokdarwis) merupakan salah satu komponen dalam masyarakat yang memiliki peran dan kontribusi penting dalam pengembangan kepariwisataan di daerahnya. Keberadaan Pokdarwis tersebut perlu terus didukung dan dibina sehingga dapat berperan lebih efektif dalam turut menggerakkan partisipasi masyarakat untuk mewujudkan lingkungan dan suasana yang kondusif bagi tumbuh dan berkembangnya kegiatan kepariwisataan di sekitar destinasi pariwisata (Rahim, 2012:3)

Bagan 1.Pemangku Kepentingan dalam

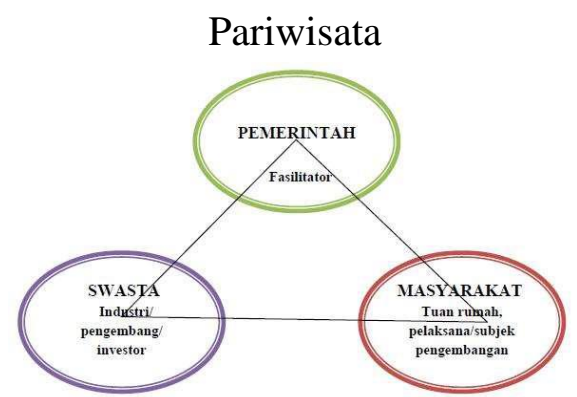

Sumber : Rahim (2012:2)

Partisipasi adalah keikutsertaan, peranserta atau keterlibatan yang berkaitan dengan keadaaan lahiriahnya (Sastropoetro dalam Murdiyanto, 2011).

Menurut Murdiyanto (2011:95) Tingkat partisipasi masyarakat dapat diukur dengan tiga pendekatan, yaitu :

a. Dimensi pemikiran, yaitu partisipasi dalam bentuk pemikiran dalam usaha mengembangkan pariwisata. Partisipasi ini terlihat dari masukan pemikiran, baik tentang bagaimana pengembangan, paket program, sampai pada media yang digunakan dalam pengembangan pariwisata.

b. Dimensi tenaga, yaitu sumbangan berupa tenaga atau fisik yang diperlukan dalam pengembangan pariwisata.

c. Dimensi materi, yaitu sumbangan berupa materi dalam pengembangan pariwisata, seperti pengumpulan dana untuk pembangunan. 
Pengembangan pariwisata berbasis masyarakat menuntut adanya partisipasi masyarakat lokal dalam tahap pembangunanya, tujuannnya agar pengelolaan pembangunan benar-benar dilakukan oleh mereka yang hidup dan kehidupannya dipengaruhi oleh pembangunan tersebut (Prasiasa 2011:104).

Pariwisata berbasis masyarakat merupakan sebuah pendekatan dalam pembangunan pariwisata yang sangat berbeda dengan pendekatan konvensional yang selama ini dijalankan, yaitu system top-down dan sentralistik (Prasiasa, 2011:95).

Indonesia menyadari kekuatan sektor pariwisata dan akan terus mengembangkan industri pariwisata di tanah air. Khususnya Sumatera Barat yang memiliki kekayaan alam melimpah, hal ini di dukung karena Sumatera Barat dilalui pegunungan bukit barisan yang menyimpan banyak kekayaan alam terutama spot-spot yang indah yang berpotensi dikembangkan sebagai objek wisata seperti: Air Terjun Nyarai, Tapian Puti \& Rumah Pohon Manang yang berada dalam Hutan Lindung Blok Bukit Barisan 1(satu).

Air Terjun Nyarai, Tapian Puti \& Rumah Pohon Manang merupakan objek wisata yang berada di Kecamatan Lubuk Alung dan Batang Anai yang dikelola oleh masyarakat setempat. Ketiga objek wisata ini merupakan objek wisata minat khusus (tracking) sehingga sangat cocok bagi anak muda pencinta alam dan suka serta ingin pertualangan.

Masyarakat setempat merupakan titik fokus dalam penyediaan akomodasi, katering, informasi, transportasi, fasilitas dan layanan untuk pengembangan ketiga objek wisata ini, oleh karena itu peneliti tertarik untuk meneliti objek wisata Air Terjun Nyarai, Tapian Puti \& Rumah Pohon Manang, yang lebih di fokuskan pada "Keterlibatan Masyarakat dalam Pengembangan Objek Wisata di Kecamatan Lubuk Alung \& Batang Anai Kabupaten Padang Pariaman

Tujuan Penelitian berdasarkan fokus masalah di atas adalah untuk mendapatkan data, mengolah, menganalisis dan membuat deskripsi tentang :

1. Pihak yang menjadi pencetus objek wisata Air Terjun Nyarai, Tapian Puti dan Rumah Pohon Manang untuk menjadi sebuah objek wisata.

2. Bentuk penjalaran keterlibatan masyarakat dalam pengembangan objek wisata Air Terjun Nyarai, Tapian Puti dan Rumah Pohon Manang.

3. Aturan yang disepakati masyarakat dalam pengelolaan objek wisata Air Terjun Nyarai, Tapian Puti dan Rumah Pohon Manang.

4. Persamaan dan perbedaan keterlibatan masyarakat dalam pengembangan objek wisata Air Terjun Nyarai, Tapian Puti dan Rumah Pohon. 
Gambar 1. Lokasi Penelitian

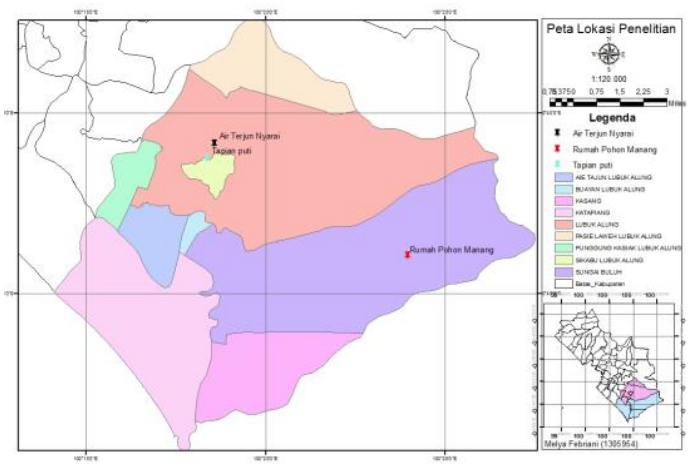

\section{METODE PENELITIAN}

\section{Jenis Penelitian}

Jenis penelitian yang digunakan adalah penelitian Deskriptif Kualitatif. Tingkat partisipasi masyarakat dalam pengembangan objek wisata ini di ukur dengan 3 pendekatan, yaitu: dimensi pemikiran, dimensi tenaga dan dimensi materi (Murdiyanto, 2011:98).

penelitian ini bertujuan untuk mendeskripsikan, serta menggambarkan secara sistematis mengenai: pencetus objek wisata Air Terjun Nyarai, Tapian Puti dan Rumah Pohon Manang. Proses keterlibatan masyarakat dalam pengembangan objek wisata Air Terjun Nyarai, Tapian Puti dan Rumah Pohon Manang. Bentuk aturan yang disepakati bersama oleh masyarakat dalam pengelolaan objek wisata Air Terjun Nyarai, Tapian Puti dan Rumah Pohon Manang. Serta persamaan dan perbedaan keterlibatan masyarakat dalam pengelolaan objek wisata Air Terjun Nyarai, Tapian Puti dan Rumah Pohon Manang.

Menggunakan jenis penelitian deskriptif kualitatif dengan metode observasi dan wawancara langsung ke lapangan, peneliti menemukan jawaban dari penelitian dengan melakukan wawancara dengan 14 orang informan, data utama dalam penelitian ini merupakan data dari hasil wawancara dengan masyarakat setempat.

\section{Setting Penelitian}

Penelitian dilakukan di tiga objek wisata yang ada di Kecamatan Lubuk Alung, dan Batang Anai yakni Air Terjun Nyarai, Tapian Puti, dan Rumah Pohon Manang yang terletak di Kabupaten Padang Pariman, Sumatera Barat.

Subjek penelitian ditentukan dengan teknik "Purposive Sampling" yaitu subjek penelitian ditentukan berdasarkan pertimbangan tertentu. Pertimbangan tertentu ini memuat orang yang dianggap paling tahu tentang yang penelitian yang dilakuakan yaitu pencetus, dan juga masyarakat sekitar yang mengetahui dan ikut serta dalam pengembangan pariwisata.

Empat belas orang (14) orang informan yang terdiri dari 1 (satu) orang informan dari Dinas Kehutanan Sumatera Barat, 1(satu) orang informan dari Dinas Pariwisata Kabupaten Padang Pariaman 2 (dua) orang informan dari Pemandu Wisata Nyarai. 2 (dua) orang informan dari Pokdarwis L.A Adventure, 1 (satu) orang informan dari masyarakat setempat di objek wisata Nyarai, 2 (dua) orang informan dari pemuda-pemudi Tapian Puti, 2 (dua) orang informan dari anggota Pokdarwis Batang Buluah, serta 1 (satu) orang informan dari anggota LPHN Sungai Buluah. 


\section{Teknik Pengumpulan Data}

Secara umum terdapat empat macam teknik pengumpulan data yaitu: observasi, wawancara, dokumentasi, dan gabungan/triangulasi. Pengumpulan data menggunakan teknik:

1. Observasi

Dalam hal ini peneliti menggunakan teknik pengumpulan data obsevasi partisipasi pasif. Partisipasi pasif merupakan teknik pengumpulan data dimana peneliti datang ketempat kegiatan orang yang diamati, yakni Air Terjun Nyarai, Tapian Puti \& Rumah Pohon Manang, akan tetapi peneliti tidak ikut dalam kegiatan yang dilakukan oleh informan.

2. Wawancara

Esterberg mengemukakan ada beberapa macam wawancara yakni: wawancara terstruktur, semiterstruktur, dan tidak berstruktur (Sugiono, 2014:316). Akan tetapi pada kali ini penelitian yang dilakukan menggunakan teknik wawancara semiterstruktur (Semistructured interview).

Wawancara semiterstruktur adalah wawancara yang lebih mendalam dengan informan (in-dept interview). Hal ini peneliti lakukan karena peneliti ingin menggali lebih dalam masalah yang peneliti teliti dari informan. Hal ini sesuai dengan tujuan wawancara semiterstruktur, yaitu untuk menemukan masalah lebih terbuka, dimana informan diminta berpendapat dan mengemukakan ide-idenya, dan disini peneliti mendengarkan dengan seksama.
Supaya hasil wawancara dapat terekam dengan baik, dan peneliti memiliki bukti telah melakukan wawancara kepada informan sebagai sumber data, maka diperlukan bantuan alat-alat sebagai berikut:

a. Buku catatan: berfugsi untuk mencatat semua percakapan dengan sumber data.

b. Tape recorder: berfusi untuk merekam semua percakapan atau pembicaraan.

c. Camera: untuk memotret kalau peneliti sedang melakukan pembicaraan dengan informan/sumberdata (Sugiono, 2014:326).

\section{Teknik Analisis Data}

Teknik analisis yang peneliti gunakan untuk menganalisis data hasil penelitian di lapangan adalah teknik analisis interaktif, yang terdiri dari reduksi data, penyajian data, dan verifikasi data. Miles dan Hubberman (1984) dalam Sugiono (2014) mengemukakan bahwa aktivitas dan analisis data kualitatif dilakukan secara interaktif dan berlansung secara terusmenerus sampai tuntas, hingga datanya sudah jenuh (Sugiono, 2014:334).

\section{Pengujian Keabsahan Data}

Uji keabsahan dalam penelitian kualitatif memiliki kriteria utama yakni: valid, reliabel, dan obyektif (Sugiono, 2014:361). Dalam penelitian ini peneliti menggunakan pengujian keabsahan data dengan teknik kredibilitas data internal menggunakan teknik triangulasi.

Triangulasi adalah teknik pemeriksaan keabsahan data yang 
memanfaatkan sesuatu yang lain diluar data untuk keperluan pengecekan atau sebagai pembanding terhadap data itu (Moleong, 2012:330).

Menurut Patton (1987:331) Triangulasi dengan sumber berarti membandingkan dan mengecek balik derajat kepercayaan suatu informasi yang diperoleh melalui waktu dan alat yang berbeda. Dalam penelitian ini pengujian keabsahan data dapat peneliti peroleh melalui jalan :

1. Membandingkan data hasil pengamatan (observasi) dengan data hasil wawancara,

2. Memandingkan apa yang dikatakan orang-orang tentang situasi penelitian dengan apa yang dikatakannya sepanjang waktu,

3. Membandingkan hasil wawancara dengan dokumentasi yang peneliti lakukan

4. Membandingkan hasil observasi dengan hasil dokumentasi yang peneliti peroleh dilapangan.

\section{HASIL PENELITIAN DAN PEMBAHASAN}

Awal mula lahirnya objek wisata yang ada di Kecamatan Lubuk Alung dan Batang Anai karena keberadaan Hutan Lindung Bukit Barisan 1 (satu). Setelah adanya peraturan Gubernur Sumatera Barat tentang perhutanan sosial, masyarakat dapat mengelola sumber daya alam yang ada di dalam hutan lindung untuk pariwisata dengan syarat harus bisa menjaga kelestarian hutan
A. Air TerjunNyarai

1. Pencetus dan awal mula lahirnya objek wisata Air Terjun Nyarai

Adanya Air Terjun yang berada di

Hutan Gamaran menyebabkan ketertarikan Ritno Kurniawan untuk mengembangkan sebuah objek wisata yang mengeksplorasikan keindahan alam tanpa perlu merusaknya dengan mengembangkan objek wisata minat khusus tracking. Ritno mengetahui keindahan Air Terjun Nyarai ini setelah diajak oleh Ajo Edi yang merupakan warga setempat. Survei awal untuk pengembangan objek wisata ini dilakukan oleh Ritno, Ajo Edi dan Yanda. Hal ini sesuai dengan apa yang di katakan Yoeti (1996:172) bahwa objek wisata atau tourism attractions adalah segala sesuatu yang menjadi daya Tarik bagi orang untuk mengunjungi suatu daerah tertentu

\section{Keterlibatan masyarakat dalam pengembangan Objek Wisata Air Terjun Nyarai}

awal mulanya Air Terjun Nyarai dikembangkan karena keinginan Ritno untuk mengembangkan objek wisata, setelah mendapat persetujuan dari masyarakat (ninik mamak dan pejabat lokal) untuk mengelola objek wisata ini, kemudian masyarakat beserta Ritno meminta izin kepada Dnas Pariwisata dan Dinas Kehutanan untuk mengelola potensi yang ada di Hutan Gamaran ini. Setelah mendapat izin, Dinas Pariwisata memberikan penyuluhan bagaimana mengelola objek wisata yang baik dan membuat organisasi Pokdarwis (Kelompok Sadar Wisata) L.A Adventure. Dinas Pariwisata 
memfasilitasi dan mencari investor untuk pengembangan objek wisata Air Terjun Nyarai, \& membantu mempromosikan objek wisata ini. Setelah objek wisata ini berkembang Ritno beserta Pokdarwis L.A Adventure meminta izin kepada dinas kehutanan untuk menjadikan Hutan Lindung Gamaran jadi hutan milik nagari melalui program perhutanan sosial yakni LPHN (lembaga pengelola hutan nagari), sehingga masyarakaat mengelola hutan dan Pokdarwis L.A Adventure dapat mengembangkan objek wisata Air Terjun Nyarai tanpa takut lagi karena sudah mendapatkan izin untuk mengelola hutan.

Gambar 2. Struktur Keterlibatan Masyarakat dalam Pengembangan

Objek Wisata Air Terjun Nyarai

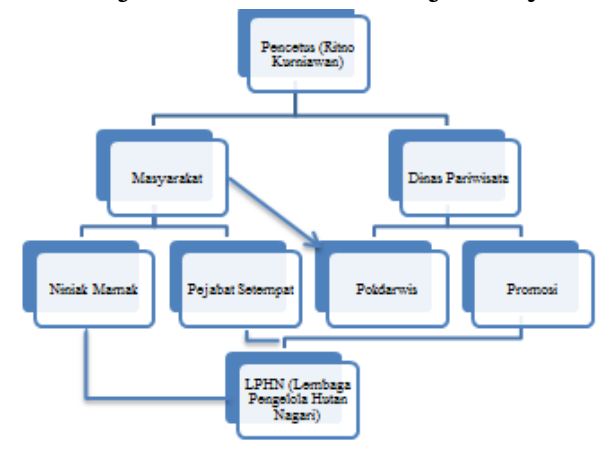

Sumber :pengolahan data primer 2017

Gambar 3. Struktur Organisasi

Pokdarwis Objek Wisata

Air Terjun Nyarai

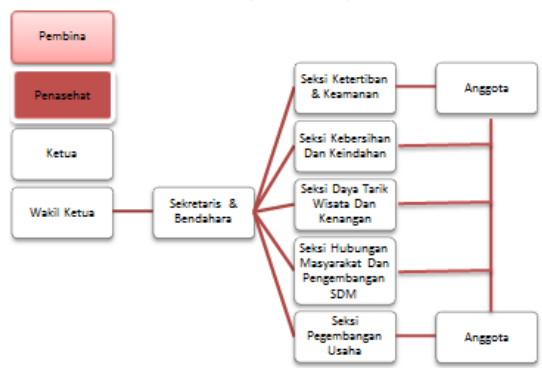

Sumber :pengolahan data primer 2017

\section{Aturan dalam pengembangan Objek Wisata Air Terjun Nyarai.}

Semua aturan dalam pengelolaan dan pengembangan objek wisata Air Terjun Nyarai tertuang dalam AD/ART Pokdarwis LA Adventure, sedangkan aturan bagi pemandu terdapat dalam kode etik pramuwisata dan aturan bagi pengunjung dapat ditemui di sepanjang jalan menuju lokasi.

\section{B. Tapian Puti}

1. Pencetus objek wisata Tapian Puti Tapian Puti merupakan objek wisata yang sudah dikenal masyarakat luas semenjak tahun 1980-an tetapi objek wisata ini mati suri atau tidak berkembang lagi karena gempa 2009. Objek wisata Tapian Puti mulai berkembang kembali setelah masyarakat merasa tertarik dengan objek wisata minat khusus seperti Nyarai, maka mulailah berkembang objek wisata minat khusus lainnya seperti Tapian Puti dan Rumah Pohon Manang dan masih banyak yang lainnya di Kabupaten Padang Pariaman. Pencetus objek wisata ini adalah Ninik Mamak dan pemuda-pemudi Sikabu Bukik. Objek wisata ini merupakan alternatif bagi wisatawan yang merasa tidak sangup untuk pergi ke Air Terjun Nyarai karena jarak tempuh yang cukup jauh. Dari Pasar Lubuk Alung menuju Air Terjun Nyarai membutuhkan waktu \pm 30 menit sedangkan ke Tapian Puti hanya membutuhkan waktu tempuh \pm 15 menit. Begitupun dengan jarak tepuh dari posko menuju lokasi Objek Wisata Air Terjun Nyarai membutuhkan waktu \pm 2 jam sedangkan ke Tapian Puti ini 
membutuhkan waktu tempuh \pm 30 menit dengan berjalan kaki atau sepeda motor.

\section{Keterlibatan Masyarakat dalam} Pengembangan Objek Wisata Tapian Puti

Objek Wisata Tapian Puti sampai sekarang idak memiliki Pokdarwis sehingga sampai sekarang objek wisata ini tidak mengalami perkembangan yang berarti.

Masyarakat yang terlibat dalam pengembangan objek wisata ini hanya niniak mamak dan pemuda setempat. Kurangnya respon masyarakat untuk mengembangkan objek wisata Tapian Puti ini, menyebabkan Dinas Pariwisata tidak dapat masuk untuk memberikan fasilitas dan membantu dalam pengembangan objek wisata ini. Hal ini sejalan apa yang dikatakan oleh Rahim (2012:2-3) bahwa masyarakat dengan sumber daya yang dimiliki, baik berupa adat, tradisi dan budaya serta kapasitasnya, berperan sebagai tuan rumah (host), namun juga sekaligus memiliki kesempatan sebagai pelaku pengembangan kepariwisataan sesuai kemampuan yang dimilikinya.

Gambar 4. Keterlibatan masyarakat dalam pengembangan objek wisata Tapian Puti

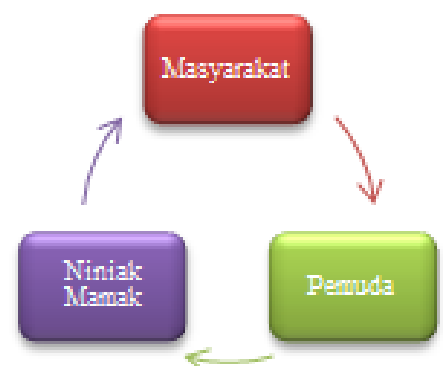

Sumber : Pengolahan Data Primer 2017

\section{Aturan dalam pengelolaan Objek Wisata Tapian Puti}

Objek Wisata Tapian Puti tidak memiliki Pokdarwis. Objek Wisata Tapian Puti ini juga tidak memiliki aturan tertulis tetapi memiliki aturan adat yang mengikat pengunjung.

\section{Rumah Pohon Manang}

1. Pencetus Objek Wisata Rumah Pohon Manang

Adanya Objek Wisata Rumah Pohon Manang karena pengembangan hutan lidung jadi hutan milik nagari (LPHN atau Lembaga Pengelola Hutan Nagari) melalui program perhutanan sosial. Pada awalnya masyarakat akan mengembangkan Sarasah Kuaw sebagai program kerja produktif dari rencana kerja LPHN, tetapi pada saat kunjungan utusan Negara Swedia (calon donatur) melakukan survei mereka bertanya kepada penduduk setempat apakah ada lokasi disini yang memiliki view atau pemandangan yang indah, dan masyarakat setempat menjawab ada. setelah melihat lokasi tersebut, donatur tersebut merasa tertarik untuk membangun rumah pohon disana dan merekalah yang memberikan dana untuk membangun Rumah Pohon Manang tersebut melalui LSM Warsi.

\section{Keterlibatan Masyarakat dalam Pengembangan Objek Wisata Rumah Pohon Manang}

Semua elemen masyarakat terlibat dalam pengembangan objek wisata Rumah Pohon Manang, termasuk Dinas Kehutanan dan Dinas Pariwisata selaku pengarah dan pemberi izin pengelolaan objek wisata. 
3. Aturan dalam pengelolaan dan pengembangan Objek Wisata Rumah Pohon Manang

Aturan dalam bentuk tertulis dibuat dalam pengelolaan objek wisata Rumah Pohon Manang. yang harus dipatuhi oleh pengunjung yang dapat dilihat dari baliho yang terpajang di depan posko. Aturan bagi pemandu wisata sama dengan aturan pemandu wisata yang ada di objek wisata Air Terjun Nyarai karena baik Pokdarwis L.A Adventure \& Pokdarwis Batang Buluah (pengelola Objek Wisata Rumah Pohon Manang) sama-sama dibina oleh Dinas Pariwisata Kabupaten Padang Pariaman. Hal ini sesuai dengan apa yang di jelaskan Rahim (2012:2-3) bahwa Pemerintah sesuai dengan tugas dan kewenangannya menjalankan peran dan fungsinya sebagai fasilitator dam pembuat peraturan (regulator) dalam kegiatan pembangunan kepariwisataan

Gambar 5. Keterlibatan Masyarakat dalam Pengembangan Objek Wisata Rumah Pohon Manang

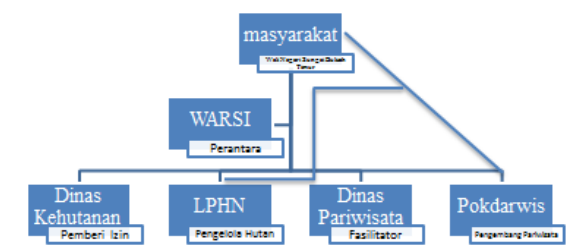

Sumber : Pengolahan Data Primer 2017

\section{Persamaan dan Perbedaan \\ Keterlibatan Masyarakat dalam Pengembangan Objek Wisata di Kabupaten Padang Pariaman.}

Pencetus dari masing-masing objek wisata berbeda-beda dari segi kelembagaannya. Setiap objek wisata memiliki pengelola, yang dalam pengelolaannya melibatkan beberapa elemen masyarakat. Aturan merupakan hal terpenting dalam pengeloaan sebuah objek pariwisata, jika tidak ada aturan dalam pengembangan dan pengelolaan objek wisata maka objek wisata tersebut tidak mengalami perkembangan, seperti yang terlihat pada Objek Wisata Tapian Puti. Berikut diringkaskan dalam bentuk bagan perbedaan dan persamaan tersebut pada tiga gambar di bawah ini.

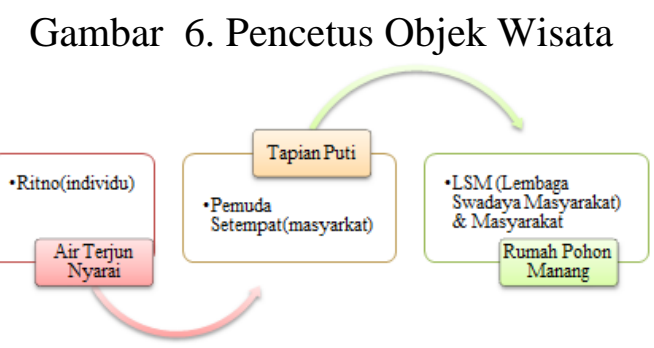

Sumber : Pengolahan Data Primer 2017

Gambar 7. Penjalaran Keterlibatan Masyarakat

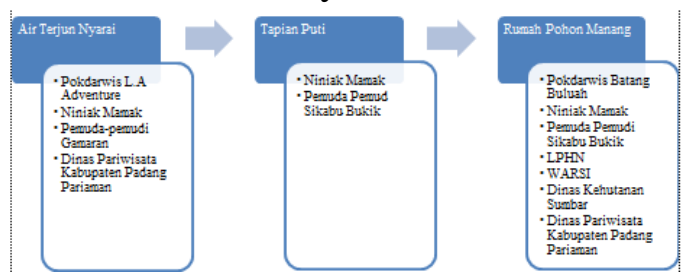

Sumber : Pengolahan Data Primer 2017

Gambar 8. Ketersediaan Aturan dalam Pengembangan Objek Wisata di Kabupaten Padang Pariaman

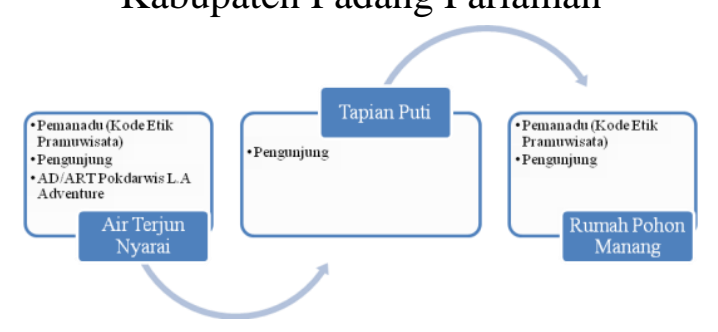

Sumber : Pengolahan Data Primer 2017 


\section{PENUTUP}

\section{Kesimpulan}

Berdasarkan hasil penelitian dan pembahasan mengenai keterlibatan masyarakat dalam pengembangan objek wisata di Kecamatan Lubuk Alung \&Batang Anai Kabupaten Padang Pariaman, Studi Kasus: Air Terjun Nyarai, Tapian Puti dan Rumah Pohon Manang dapat disimpulkan bahwa:

1. Pencetus objek wisata Air Terjun Nyarai adalah Ritno Kurniawan (individu), sedangkan pencetus objek wisata Tapian Puti adalah Pemuda-Pemudi Sikabu Bukik. Sedikit berbeda dengan kedua objek wisata di atas yang menjadi pencetus objek wisata Rumah Pohon Manang adalah masyarakat beserta LSM (Lembaga Swadaya Masyarakat).

2. Penjalaran Keterlibatan masyarakat dalam pengembangan objek wisata Air Terjun Nyarai di mulai dari individu, kemudian pokdarwis baru terbentuklah LPHN. Sedangkan Tapian Puti yang terlibat dalam pengembangan objek wisata ini hanya niniak mamak dan pemuda setempat. Objek wisata Rumah Pohon Manang berkembang dari LPHN kemudian ada potensi, kemudian baru dibentuklah pokdarwisnya.

3. Aturan dalam pengeloaan ketiga objek wisata ini sama-sama terikat oleh aturan adat, tapi di objekwisata Air Terjun Nyarai \& Rumah Pohon Manang memiliki aturan tertulis untuk pengelolaan dan pramuwisatanya yang harus mereka taati.

4. Persamaan dari ketiga objek wisata ini adalah: merupakan objek wisata minat khusus, berada pada blok bukit barisan 1(satu). Sedangkan perbedaannya dapat terlihat dari cara terbentuk masing-masing objek wisata ini berbeda-beda. Air Terjun Nyarai terbentuk karena ide Ritno Kurniawan, Tapian Puti berkembang lagi karena ide dari pemuda-pemudi Sikabu Bukik dan Rumah Pohon Manang terbentuk karena ide dari LSM (Lembaga Swadaya Masyarakat) beserta masyarakat setempat.

\section{Saran}

Pada bagian ini penulis mencoba memberi saran-saran sebagai berikut:

1. Sumatera Barat perlu mengembangkan berbagai elemen masyarakat baik dalam bentuk kelompok maupun individu sebagai pencetus dimulainya keberadaan objek wisata pada suatu lokasi yang berpotensi menjadi objek wisata

2. Pola-pola pelibatan seluruh elemen masyarakat perlu dibuat dengan meniru keberhasilan dari pengembangan objek wisata yang telah berhasil.

3. Sebaiknya setiap objek wisata perlu membuat kesepakatan tertulis dengan masyarakat yang ikut berpartisipasi dalam mengelola suatu objek wisata.

4. Kondisi masyaratkat akan berbeda pada setiap objek wisata, oleh sebab itu kemampuan mengenal karakteristik masyarakat di objek 
wisata akan sangat bermanfaat untuk pengembangan objek wisata.
Yoeti, Oka A. 2003. Pengantar Ilmu Pariwisata. Bandung : Angkasa

\section{DAFTAR PUSTAKA}

Aref, Fariborz dkk. 2010. Tourism Development in Local Communities: As a Community Development Approach. Journal of American Science : Volume 6 (2)

Bakarudin. 2008. Perkembangan dan Permasalahan Kepariwisataan. UNP PRESS: Padang

Murdiyanto, Eko. 20011. Partisipasi Masyarakat dalam Pengembangan Desa Wisata Karanggeneng, Purwobinagon, Pakem. SEPA: Volume7

Moleong, J. Lexy. 2012. Metodologi Penelitian Kualitatif. Bandung : Remaja Rosda Karya

Patton, M. Q. 1987. How to Use Qualitative Methods in Evaluation. California: Sage Publications, Inc

Prasiasa, Dewa Putu Oka. 2011. Wacana Kontemporer Pariwisata. Jakarta :Salemba Humanika

Rahim., Firmansyah. 2012. Pedoman Kelompok Sadar Wisata. Jakarta : Kementerian Pariwisata dan Ekonomi Kreatif

Sugiono. 2014. Metode penelitian kuntitatif, kulitatif, dan kombinasi (mixed Methods). Yogyakarta : Alfabeta

Suwanto, Gamal. 2004. dasar-dasar pariwisata. Yogyakarta : Andi

Undang-Undang Republik Indonesia No 10 Tahun 2009 Tentang Kepariwisataan 